\title{
Nursing care of a child with type 1 diabetes mellitus - a nursing process using the International Classification of Nursing Practice ICNP ${ }^{\otimes}$
}

\author{
Opieka pielęgniarska nad dzieckiem z cukrzycą typu 1 - proces pielęgnowania zzastosowaniem \\ Międzynarodowej Klasyfikacji Praktyki Pielęgniarskiej ICNP®
}

\section{Julita Ronkowska ${ }^{1,2} \odot$, Anna Stefanowicz-Bielska ${ }^{3,4} \odot$}

'student of a Bachelor's degree in Nursing program, Faculty of Health Sciences with Institute of Maritime and Tropical Medicine, Medical University of Gdansk/ studentka Studiów Licencjackich, kierunek Pielęgniarstwo, Wydział Nauk o Zdrowiu z Instytutem Medycyny Morskiej i Tropikalnej, Gdański Uniwersytet Medyczny ${ }^{2}$ student Science Club of Pediatric Nursing, Faculty of Health Sciences with Institute of Maritime and Tropical Medicine, Medical University of Gdansk/ Studenckie Koło Naukowe Pielęgniarstwa Pediatrycznego, Wydział Nauk o Zdrowiu z Instytutem Medycyny Morskieji Tropikalnej, Gdański Uniwersytet Medyczny ${ }^{3}$ Laboratory of Pediatric Nursing, Department of Internal and Pediatric Nursing, Institute of Nursing and Midwifery, Faculty of Health Sciences with Institute of Maritime and Tropical Medicine, Medical University of Gdansk/ Pracownia Pielęgniarstwa Pediatrycznego, Zakład Pielęgniarstwa Internistyczno-Pediatrycznego, Instytut Pielęgniarstwa i Położnictwa, Wydział Nauk o Zdrowiu z Instytutem Medycyny Morskiej i Tropikalnej, Gdański Uniwersytet Medyczny ${ }^{4}$ Polish Federation for Education in Diabetology/Polska Federacja Edukacji w Diabetologii

\section{CORRESPONDING AUTHOR/AUTOR DO KORESPONDENCJ: \\ Anna Stefanowicz-Bielska \\ Pracownia Pielęgniarstwa Pediatrycznego, Zakład Pielęgniarstwa Internistyczno-Pediatrycznego, Instytut Pielęgniarstwa i Położnictwa, Wydział Nauk o Zdrowiu z Instytutem Medycyny Morskiej i Tropikalnej, \\ Gdański Uniwersytet Medyczny ul. Dębinki 7, 80-952 Gdańsk e-mail: ania-stefanowicz@gumed.edu.pl}

\section{STRESZCZENIE OPIEKA PIELEGNIARSKA NAD DZIECKIEM Z CUKRZYCA TYPU 1 - PROCES PIELĘGNOWANIA Z ZASTOSOWANIEM} MIEDZYNARODOWEJ KLASYFIKACJI PRAKTYKI PIELEGNIARSKIEJ ICN PO

Wprowadzenie. Cukrzyca typu 1 jest najczęstszą, przewlekłą chorobą wieku dziecięcego.

Cel pracy. Celem pracy jest przedstawienie procesu pielęgnowania dziecka z DMT1 i jego rodziny z zastosowaniem terminologii z ICNP® Materiał i metody. W pracy posłużono się metodą indywidualnego przypadku oraz analizą piśmiennictwa. Badanie zostało przeprowadzone w grudniu 2019 roku. Na przeprowadzenie badania uzyskano pisemną zgodę Matki dziecka.

Wyniki i podsumowanie. Właściwa opieka pielęgniarska, intensywna edukacja diabetologiczna oraz optymalne leczenie jest niezbędne, aby zapewnić najlepszą jakość życia minimalizując jednocześnie ryzyko wystąpienia ostrych zaburzeń metabolicznych i przewlekłych powikłań. Stosowanie terminologii z ICNP ${ }^{\circledast}$ umożliwia stworzenie szczegółowego i holistycznego procesu pielęgnowania nad dzieckiem z DMT1 i jego rodziną. Na podstawie uzyskanych informacji sformułowano diagnozy pielęgniarskie: duszność, nudności, hiperglikemia, hipoglikemia, brak wiedzy o chorobie, brak wiedzy o reżimie leczenia, brak wiedzy o reżimie diety, nadwaga, niepokój, zaburzona socjalizacja, ryzyko zaburzenia zdolności do sprawowania opieki rodzicielskiej. Podjęte interwencje pielęgniarskie pomogą osiągnąć odpowiedni poziom życia oraz obniżą ryzyko wystąpienia ostrych zaburzeń metabolicznych oraz przewlekłych powikłań cukrzycy.

Słowa kluczowe: dziecko, proces pielęgnowania, cukrzyca, Międzynarodowa Klasyfikacja Praktyki Pielęgniarskiej

ABSTRACT NURSING CARE OF A CHILD WITH TYPE 1 DIABETES MELLITUS - A NURSING PROCESS USING THE INTERNATIONAL CLASSIFICATION OF NURSING PRACTICEICNP

Introduction. Type 1 diabetes is the most common chronic childhood disease.

Aim. The aim of the study is to present the process of nursing a child with DMT1 and its family using the terminology from ICNP ${ }^{\circledast}$. Material and methods. The study is based on a case report and a literature review. The study was conducted in December 2019. A written consent of the child's mother was obtained for the study.

Results and conclusions. Proper nursing care, intensive diabetes education and optimal treatment are essential to ensure the best quality of life while minimizing the risk of acute metabolic disorders and chronic complications. Using ICNP ${ }^{\oplus}$ terminology enables the creation of a detailed and holistic nursing process for a child with DMT1 and its family. Based on the information obtained, nursing diagnoses were formulated: dyspnea, nausea, hyperglycaemia, hypoglycaemia, lack of knowledge of illness, lack of knowledge of treatment regime, lack of knowledge of diet regime, overweight, anxiety, impaired socialization, risk of impaired parenting. The nursing interventions will help to achieve an appropriate standard of living as well as reduce the risk of acute metabolic disorders and chronic diabetes complications. 


\section{INTRODUCTION}

Diabetes Mellitus type 1 (DMT1) is the most common chronic childhood disease $[1,2,3]$.

DMT1 therapy includes intensive subcutaneous insulin administration in doses calculated on the basis of carbohydrate intake, exercise and capillary blood glucose measurement. In childhood and adolescence, improper glycemic control may lead to acute metabolic disorders and chronic complications, memory and cognitive impairment, and depression [1,2,3].

Intensive treatment and nursing, regular monitoring of the disease and constant attention of children and their parents are often a source of chronic stress $[1,2,3]$.

The system supporting general and specialized nursing practice in various institutions is, inter alia, the International Classification for Nursing Practice $\left(\mathrm{ICNP}^{\circledast}\right)[4,5]$.

$\mathrm{ICNP}^{\circledast}$ allows the formulation of phrases referring to diagnoses, nursing actions (interventions) or obtained results of care. It consists of seven axes including: subject of care (Focus - F), action, client (C), judgment (J), location $(\mathrm{L})$, time $(\mathrm{T})$, means used $(\mathrm{M})[4,5,6]$.

\section{AIM}

The aim of the study is to present the process of nursing a child with DMT1 and its family using ICNP ${ }^{\circledR}$ terminology.

\section{MATERIAL AND METHODS}

The study is based on a case report and a literature review. The techniques used include interview, observation and analysis of the patient's medical records.

The research tools used were scientific articles, an original interview questionnaire prepared by the researcher, hospital discharge summaries, a self-control diary, a height measuring rod, scales and a glucometer. The study was conducted in December 2019. A written consent of the child's mother was obtained for the study.

\section{The case report}

A 4-year-old girl and her grandmother were admitted to the Emergency Department due to general weakness, tachypnea and nausea.

Capillary blood glucose levels were measured with a glucometer. Blood glucose level was $408 \mathrm{mg} \%$. The initial diagnosis was de novo diabetes. The patient was taken by air transport to the Diabetes Department for Children.

On admission to the diabetes ward, the child's general condition was severe. The patient was cardiovascularly and respiratorily stable, drowsy, with impaired verbal-logical contact, not answering the questions asked. Basic vital signs on admission to the department were: 30 breaths / minute, heart rate 130 beats / minute, blood pressure 100/70 mmHg. A physical examination showed rapid breathing (tachypnea), dry mouth, Kussmaul breathing, enlarged tonsils, and reddening of the throat.

The doctor ordered laboratory tests of blood and urine.
Blood glucose level was $181 \mathrm{mg} \%$ and glycosylated hemoglobin level (HbA1c) was $11.2 \%$. The urine test showed the presence of glucose and ketones.

The doctor's diagnosis was severe ketoacidosis in the course of newly diagnosed type 1 diabetes and ordered intravenous hydration, intravenous insulin therapy, antibiotic therapy and oxygen therapy. A peripheral venipuncture and a Foley catheter into the bladder were placed. Vital signs were intensively monitored with a cardiac monitor and pulse oximeter.

In the following days of hospitalization, the patient's condition improved and stabilized. The child was conscious, responsive, with full verbal-logical contact, vital parameters were normal, and further treatment of type 1 diabetes was continued.

During hospitalization, the patient underwent intensive subcutaneous insulin therapy using a personal insulin pump, and followed a low glycemic diet according to carbohydrate and protein-fat exchangers.

During the stay in the ward, the child and the mother were under the care of a psychologist and had nutritional and diabetes education on self-control and type 1 diabetes therapy with a personal insulin pump.

The patient was discharged from the hospital with the following nursing recommendations: continuation of intensive subcutaneous insulin therapy according to medical orders, following a low glycemic diet according to carbohydrate and protein-fat exchangers, systematic self-monitoring, regular physical activity and regular control at the Diabetes Clinic for Children.

The patient was delivered in spontaneous labour in the $38^{\text {th }}$ week of pregnancy. It was the second childbirth and the second pregnancy of the mother. The pregnancy was normal. The newborn child received 10 points on the Apgar scale. The child is vaccinated according to the vaccination schedule.

The patient has no other coexisting diseases. Hypothyroidism and hyperthyroidism are present in the family. The child's psychomotor development is correct.

At the time of the study, the patient's body weight was $21.5 \mathrm{~kg}$, height $110 \mathrm{~cm}$, Body Mass Index $17.8 \mathrm{~kg} / \mathrm{m}^{2}$.

Currently, the girl and her parents are at home. They are good at calculating carbohydrate and protein-fat exchangers and operating a personal insulin pump.

The mother understands how to implement the principles of self-control and treatment of type 1 diabetes. The child's father cannot come to terms with the medical diagnosis. He is trying to find an explanation for his daughter's disease and is searching for alternative treatments for diabetes. The mother's greatest fear is that she will not find a suitable kindergarten for her daughter.

The patient's mother is also afraid of going back to work and leaving her daughter in an educational institution. 


\section{The process of nursing a patient with the use of ICNP® terminology}

The subject of care: child 10004266 [7]

Location: hospital ward 10009133[7]

Judgement: dyspnoea 10029433 + metabolic acidosis 10032010 [7]

Aim: no dyspnoea 10029264 + effective acid base

balance 10033663 [7]

Interventions:

- medication handling 0040708, means/object: insulin 10010400, nurse 10013333, medication administration technique 10006322, venous cannula 10020677, metabolic acidosis 10032010 [7];

- fluid therapy 10039330, means/object: nurse 10013333, fluid therapy 10031321, venous cannula 10020677 [7];

- monitoring respiratory status 10012196 , means/object: nurse 10013333, assessment tool 10002832 [7];

- skin assessment 10041126, means/object: nurse 10013333, assessment tool 10002832 [7];

- supporting psychological status 10019161, means/ object: nurse 10013333, education service 10006572 [7];

- managing symptom 10031965, means/object: nurse 10013333, physician 10014522, dyspnoea 10006461, metabolic acidosis 10032010 [7]

Outcome: no dyspnoea 10029264 + effective acid base balance 10033663 [7]

The subject of care: child 10004266 [7]

Location: hospital ward 10009133 [7]

Diagnosis: nausea 10000859 + metabolic acidosis $10032010[7]$

Aim: no nausea $10028984+$ effective acid base balance 10033663 [7]

Interventions:

- medication handling 0040708, means/object: insulin 10010400, nurse 10013333, medication administration technique 10006322, venous cannula 10020677, metabolic acidosis 10032010 [7];

- fluid therapy 10039330, means/object: nurse 10013333, fluid therapy 10031321, venous cannula 10020677 [7];

- managing vomiting 10046329 , means/object: nurse 10013333, medication 10011866, fluid therapy 10031321, grooming device 10008537 [7];

- managing nausea 10043673 , means/object: nurse 10013333, medication 10011866, fluid therapy $10031321[7] ;$

- monitoring physiological status 10012183, means/ object: nurse 10013333, assessment tool 10002832 [7]

Outcome: no nausea 10028984 + effective acid base balance 10033663 [7]

The subject of care: child 10004266 [7]

Location: hospital ward 10009133, home 10009030 [7]

Diagnosis: hyperglycaemia 10027550 [7]

Aim: effective response to therapy 10036423 [7]

Interventions:

- measuring blood glucose 10041212, means/object: monitoring device 10012177 [7];
- administering medicine 100255444 , means/object: insulin 10010400, nurse 10013333, medication administration technique 10006322, venous cannula 10020677 [7];

- demonstrating medication administration 100243544, means/object: nurse 10013333, instructional material 10010395 [7];

- monitoring physiological status 10012183, means/ object: nurse 10013333, assessment tool 10002832 [7];

- teaching about treatment regime 10024625, means/ object: nurse 10013333, instructional material 10010395, nutritionist 10040426 [7];

- teaching family about disease 10021719 , means/object: nurse 10013333, instructional material 10010395, reading material 10016433 [7]

Outcome: effective response to therapy 10036423 [7]

The subject of care: child 10004266 [7]

Location: hospital ward 10009133, home 10009030 [7]

Diagnosis: hypoglycemia 10027566 [7]

Aim: effective response to therapy 10036423[7] Interventions:

- measuring blood glucose 10041212, means/object: monitoring device 10012177 [7];

- monitoring physiological status 10012183, means/ object: nurse 10013333, assessment tool 10002832 [7];

- administering medicine 100255444, means/object: insulin 10010400, nurse 10013333, medication administration technique 10006322 [7];

- teaching about treatment regime 10024625, means/ object: nurse 10013333, instructional material 10010395, nutritionist 10040426 [7];

- teaching family about disease 10021719 , means/object: nurse 10013333, instructional material 10010395, reading material 10016433 [7]

Outcome: effective response to therapy 10036423 [7]

The subject of care: child 10004266, family 10007554[7] Location: hospital ward 10009133, home 10009030[7] Diagnosis: lack of knowledge of disease 10021994 [7]

Aim: adequate knowledge 10027112[7] Interventions:

- accessing knowledge of disease 10030639, means/ object: nurse 10013333, assessment tool 10002832 [7];

- demonstrating medication administration 10024354, means/object: nurse 10013333, insulin 10010400, health education service 10039459, instructional material 10010395 [7];

- teaching about disease 10024116, means/object: nurse 10013333, health education service 10039459, instructional material 10010395, reading material 10016433 [7];

- providing instructional material 10024493, means/ object: instructional material 10010395 [7];

- assessing adherence 10024185, means/object: nurse 10013333, assessment tool 10002832 [7];

- administering insulin 10030417, means/object: nurse 10013333, insulin 10010400 [7]

Outcome: adequate knowledge 10027112 [7] 
The subject of care: child 10004266, family 10007554 [7] Location: hospital ward 10009133, home 10009030 [7] Diagnosis: lack of knowledge of treatment regime 10021925 [7]

Aim: adequate knowledge 10027115 [7]

Interventions:

- demonstrating medication administration 10024354 , means/object: nurse 10013333, insulin 10010400, health education service 10039459 , instructional material 10010395 [7];

- teaching about medication 10019470, means/object: nurse 10013333, insulin 10010400, health education service 10039459 , instructional material 10010395 , reading material 10016433 [7];

- administering medicine 100255444, means/object: nurse 10013333, insulin 10010400 [7];

- identifying attitude toward care 10009649, means/ object: nurse 10013333, assessment device 10002734 [7];

- assessing attitude toward treatment regime 10024205 , means/object: nurse 10013333, assessment device 10002734 [7]

Outcome: adequate knowledge 10027115 [7]

The subject of care: child 10004266, family 10007554 [7] Location: hospital ward 10009133, home 10009030 [7] Diagnosis: lack of knowledge of dietary regime 10021939 [7]

Aim: knowledge of dietary regime 10023772 [7]

Interventions:

- teaching about diet 10046533, means/object: nurse 10013333, health education service 10039459, instructional material 10010395 [7];

- assessing knowledge 10033882, means/object: nurse 10013333, assessment device 10002734 [7];

- teaching about nutrition 10024618, means/object: nurse 10013333, health education service 10039459 , instructional material 10010395 [7];

- evaluating psychosocial response to instruction about nutrition 10007111, means/object: nurse 10013333, assessment device 10002734 [7]

Outcome: knowledge of dietary regime 10023772 [7]

The subject of care: child 10004266 [7]

Location: hospital ward 10009133, home 10009030 [7]

Diagnosis: overweight 10027300 [7]

Aim: weight within normal limits 10027392 [7]

Interventions:

- monitoring weight 10032121 , means/devices: nurse 10013333, assessment device 10002734 [7];

- monitoring nutrition 10036032, means/devices nurse 10013333, assessment device 10002734 [7];

- teaching about nutrition 10024618, means/object: nurse 10013333, health education service 10039459 , instructional material 10010395 [7];

- assessing attitude toward nutritional status 10002694 , means/ devices: nurse 10013333, assessment device 10002734 [7];

- collaborating with nutritionist 0040435, means/object: nutritionist 10040426, nutritionist service 10013435 [7];
- providing instructional material 10024493, means/ object: instructional material 10010395 [7];

- advancing dietary regime 10036447: means/object: nurse 10013333, nutritionist 10040426, assessment device 10002734, reading material 10016433 [7]

Outcome: weight within normal limits 10027392 [7]

The subject of care: family 10007554[7]

Location: hospital ward 10009133, home 10009030 [7] Diagnosis: anxiety 10000477 + hospitalisation 10009122 [7]

Aim: reduced anxiety 10027858 [7]

- assessing anxiety 10041745, means/object: nurse 10013333, assessment device 10002734 [7];

- managing anxiety 10031711, means/object: nurse 10013333[7];

- use calming technique 10050299 , means/object: nurse 10013333[7];

- demonstrating relaxation technique 10024365, means/ object: nurse 10013333 [7];

- promoting positive psychological status 10032505 , means/object: nurse 10013333 [7];

- informing about hospitalisation 10042480, means/ object: nurse 10013333, physician 10014522 [7];

- implementing comfort care 10039705, means/object: nurse 10013333, grooming device 10008537 [7];

- accompanying patient 10042613, means/object: nurse 10013333;

- providing emotional support 10027051, means/object: nurse 10013333 [7]

Outcome: reduced anxiety 10027858 [7]

The subject of care: child 10004266, family 10007554 [7]

Location: home 10009030, school 10017537 [7]

Diagnosis: impaired socialisation 10001022 [7]

Aim: able to socialise 10028282 [7]

Interventions:

- teaching community about disease 10038203 , means/ object: nurse 10013333, instructional material 10010395, reading material 10016433 [7];

- teaching school service about disease 10038226 , means/object: nurse 10013333, instructional material 10010395, reading material 10016433 [7];

- assessing capabilities 10026040, means/object: nurse 10013333, assessment device 10002734 [7];

- identifying obstruction to communication 10009683, means/object: nurse 10013333, assessment device 10002734 [7];

- assessing attitude toward treatment regime 10025205 , means/object: nurse 10013333, assessment device 10002734 [7];

- assessing family coping 10026600 , means/object: nurse 10013333 , assessment device 10002734 , social worker 10024088 [7];

- assessing social support 10024298, means/object: nurse 10013333, social worker 10024088 [7]

Outcome: able to socialise 10028282 + school 10017537 [7] 
The subject of care: family 10007554 [7]

Location: home 10009030 [7]

Diagnosis: risk for impaired parenting 10015198 [7]

Aim: effective parenting 10027955 [7]

Interventions:

- providing emotional support 10027051, means/object: nurse 10013333, physician 10014522, psychological process 10015961 [7];

- collaborating with physician 10023565 , means/object: physician 10014522 [7];

- assessing anxiety 10041745 , means/object: nurse 10013333, assessment device 10002734 [7];

- managing anxiety 10031711, means/object: nurse 10013333, psychological response 10015974, health care provider 10003989 [7];

- promoting family support 10036078 , means/object: nurse 10013333 , social worker 10024088 , family therapy 10007667 [7];

- collaborating with family 10035887 , means/object: nurse 10013333, family therapy 10007667 [7]

Outcome: effective parenting 10027955 [7]

\section{DISCUSSION}

Diabetes mellitus is a contemporary social and lifestyle disease. It is a group of metabolic diseases characterized by hyperglycemia resulting from the defect in insulin secretion and/or activity. Chronic hyperglycemia in diabetes leads to damage, dysfunction and failure of many organs, mainly the eyes, kidneys, nerves, heart and blood vessels $[8,9,10]$.

Type 1 diabetes is one of the most common chronic diseases of developmental age. In recent years, there has been a steady increase in the incidence worldwide $[11,12]$.

According to the International Diabetes Federation (IDF), 1.1 million children and adolescents under the age of 20 worldwide have type 1 diabetes [10].

It is estimated that by 2025 the number of cases in Poland will increase fourfold, and will especially affect children aged 0-9 [13,14].

The clinical symptoms of type 1 diabetes depend on the age of onset. The younger the age of onset, the more turbulent the appearance and development of clinical symptoms. They are mainly associated with hyperglycemia and osmotic diuresis. Some clinical symptoms occur during treatment and are related to the administration of insulin or its incorrect dosage [15].

The most common and serious complication of diabetes treatment is hypoglycemia. Hypoglycemia has been recognized as a limiting factor in the treatment of type 1 diabetes $[16,17,18]$.

The aim of treating type 1 diabetes mellitus is to achieve good metabolic control, while maintaining blood glucose, glycosylated hemoglobin (HbA1c $\leq 7.0 \%)$, blood pressure, lipid parameters, and body weight within normal limits, at the same time avoiding hypoglycemia. An additional goal of treating children, adolescents and young adults with type 1 diabetes is to achieve and maintain proper, harmonious physical development (height and weight) and the course of puberty appropriate to age and sex, while ensuring the comfort of life of the children and their families [9].

In metabolic control, the aim is to maintain $\mathrm{HbAlc}$ levels $\leq 6.5 \%$ with stable blood glucose levels and to minimize hypoglycemic episodes. This procedure allows to prevent the occurrence of acute and chronic complications and enables patients to lead a normal and active family, professional and social life [9].

Chronic diseases require continuous active treatment. They require using various techniques and maintaining regular contact with various members of the therapeutic team [19].

Children and adolescents with type 1 diabetes and their caregivers should be actively involved in the treatment process. Treatment of type 1 diabetes includes adequate insulin therapy, proper nutrition, exercise, health education and self-monitoring by patients $[9,20,21]$.

Caring for a child with type 1 diabetes is associated with the risk of parental burnout syndrome. It is believed that professional psychological care for a child with type 1 diabetes should also include its family $[22,23,24]$.

$\mathrm{ICNP}^{\circledR}$ is a simple, standardized tool supporting general and specialist nursing care $[4,5,25]$. It enables the replacement of most of the "traditional” diagnoses and nursing activities undertaken in relation to patients with diabetes and their families with "ready” terminology from the ICNP ${ }^{\circledR}$ dictionary [25].

\section{CONCLUSIONS}

Proper nursing care, intensive diabetes education and optimal treatment are essential to ensure the best quality of life while minimizing the risk of acute metabolic disorders and chronic complications.

Using $\mathrm{ICNP}^{\circ}$ terminology enables the creation of a detailed and holistic nursing process for a child with DMT1 and its family.

On the basis of the obtained information, nursing diagnoses were formulated: dyspnoea, nausea, hyperglycemia, hypoglycemia, lack of knowledge about the disease, lack of knowledge of treatment regime, lack of knowledge about the diet regime, overweight, anxiety, impaired socialization, risk of impaired socialization, risk of impaired parenting.

The nursing interventions will help to achieve an appropriate standard of living as well as reduce the risk of acute metabolic disorders and chronic diabetes complications. 


\section{Opieka pielęgniarska nad dzieckiem z cukrzycą typu 1 - proces pielęgnowania z zastosowaniem Międzynarodowej Klasyfikacji Praktyki Pielęgniarskiej ICNP ${ }^{\circledast}$}

\section{WPROWADZENIE}

Cukrzyca typu 1 (Diabetes Mellitus type 1, DMT1) jest najczęstszą, przewlekłą chorobą wieku dziecięcego $[1,2,3]$.

Terapia DMT1 obejmuje intensywne podskórne podanie insuliny w dawkach obliczonych na podstawie ilości spożywanych węglowodanów, aktywności fizycznej i pomiaru stężenia glukozy we krwi włośniczkowej. W dzieciństwie i okresie dojrzewania nieprawidłowa kontrola glikemii może doprowadzić do wystąpienia ostrych zaburzeń metabolicznych i przewlekłych powikłań, zaburzeń pamięci i funkcji poznawczych oraz depresji $[1,2,3]$.

Intensywne leczenie i pielęgnowanie, regularne monitorowanie choroby oraz stała uwaga dzieci i ich rodziców często jest źródłem przewlekłego stresu [1,2,3].

Systemem wspierającym ogólną i specjalistyczną praktykę pielęgniarską w różnych placówkach jest między innymi Międzynarodowa Klasyfikacja Praktyki Pielęgniarskiej (International Classification for Nursing Practice, $\left.\mathrm{ICNP}^{\circledast}\right)[4,5]$.

ICNP $^{\circledast}$ umożliwia formułowanie wyrażeń nazywających diagnozy, działania (interwencje) pielęgniarskie czy uzyskiwane wyniki opieki. Składa się z siedmiu osi obejmujących: przedmiot opieki (F - Focus), działanie, klienta (C - Client), osąd (J - Judgement), lokalizację (L - Location), czas ( $\mathrm{T}$ - Time), stosowane środki działania ( $\mathrm{M}$ Means) $[4,5,6]$.

\section{CEL PRACY}

Celem pracy jest przedstawienie procesu pielęgnowania dziecka z DMT1 i jego rodziny z zastosowaniem terminologii z ICNP ${ }^{\circledast}$.

\section{MATERIAŁ I METODY}

W pracy posłużono się metodą indywidualnego przypadku oraz analizą piśmiennictwa. Zastosowano technikę wywiadu, obserwacji i analizy dokumentacji medycznej chorego.

Jako narzędzia badawcze wykorzystano artykuły naukowe, autorski kwestionariusz wywiadu, wypisy ze szpitali, dzienniczek samokontroli, wzrostomierz, wage i glukometr.

Badanie zostało przeprowadzone w grudniu 2019 roku. Na przeprowadzenie badania uzyskano pisemną zgodę Matki dziecka.

\section{Opis przypadku}

4-letnia dziewczynka wraz z babcią, została przyjęta na Oddział Ratunkowy z powodu ogólnego osłabienia, przyśpieszonego oddechu i nudności.
Zmierzono poziom glikemii z krwi włośniczkowej przy pomocy glukometru. Poziom glikemii wynosił 408 mg\%. Postawiono wstępną diagnozę cukrzyca de novo. Pacjentka została przewieziona transportem lotniczym na Oddział Diabetologiczny dla Dzieci.

Przy przyjęciu na oddział diabetologiczny stan ogólny dziecka był ciężki. Pacjentka była krążeniowo-oddechowo wydolna, podsypiająca, $\mathrm{z}$ utrudnionym kontaktem słowno-logicznym, nie odpowiadająca na zadawane pytania. Podstawowe parametry życiowe w czasie przyjęcia w oddział wynosiły: 30 oddechów/minutę, akcja serca 130 uderzeń/minutę, ciśnienie tętnicze krwi 100/70 mmHg. W badaniu fizykalnym stwierdzono przyśpieszony oddech (tachypnoe), suchość śluzówek jamy ustnej, oddech Kussmaula, powiększone migdałki oraz zaczerwienienie gardła.

Lekarz zlecił badania laboratoryjne krwi i moczu.

Wartość glikemii wynosiła $181 \mathrm{mg} \%$, stężenie hemoglobiny glikowanej (HbA1c) 11.2\%. W badaniu ogólnym moczu wykazano obecność glukozy i ketonów.

Lekarz rozpoznał ciężką kwasicę ketonową w przebiegu noworozpoznej cukrzycy typu 1 i zlecił dożylne nawadnianie, insulinoterapię dożylną, antybiotykoterapię oraz tlenoterapię. Założono wkłucie obwodowe, cewnik Foleya do pęcherza moczowego. Parametry życiowe były intensywne monitorowane przy pomocy kardiomonitora i pulsoksymetru.

W kolejnych dobach hospitalizacji stan pacjentki uległ poprawie i stabilizacji. Dziecko było przytomne, świadome, z pełnym kontaktem słowno-logicznym, parametry życiowe w normie, kontynuowano dalszą terapię cukrzycy typu 1.

W trakcie hospitalizacji wprowadzono u pacjentki intensywną insulinoterapię podskórną za pomocą osobistej pompy insulinowej i zastosowano dietę o niskim indeksie glikemicznym według wymienników węglowodanowych i wymienników białkowo-tłuszczowych.

W trakcie pobytu na Oddziale dziecko wraz z matką przebywało pod opieką psychologa oraz odbyło edukację żywieniową i diabetologiczną dotyczącą samokontroli i terapii cukrzycy typu 1 za pomocą osobistej pompy insulinowej.

Pacjentkę wypisano ze szpitala $\mathrm{z}$ następującymi zaleceniami pielęgniarskimi kontynuacja intensywnej insulinoterapii podskórnej według zleceń lekarskich, stosowanie diety o niskim indeksie glikemicznym według wymienników węglowodanowych i wymienników białkowo-tłuszczowych, systematyczna samokontrola, regularna aktywność fizyczna oraz regularna kontrola w Poradni Diabetologicznej dla Dzieci.

Pacjentka została urodzona siłami natury w 38. tygodniu ciąży. To był drugi poród oraz druga ciąża matki. Ciąża przebiegała prawidłowo. Noworodek otrzymał 10 
punktów w skali Apgar. Dziecko jest szczepione zgodnie z kalendarzem szczepień.

U pacjentki nie występują inne choroby współistniejące. W rodzinie dziecka występuje niedoczynność i nadczynność tarczycy. Rozwój psychoruchowy dziecka jest prawidłowy.

W czasie prowadzenia badań masa ciała pacjentki wynosiła $21.500 \mathrm{~kg}$, wzrost $110 \mathrm{~cm}$, Body Mass Index $17.8 \mathrm{~kg} / \mathrm{m}^{2}$.

Obecnie dziewczynka i jej rodzice są w domu. Radzą sobie dobrze $\mathrm{z}$ wyliczaniem wymienników węglowodanowych i wymienników białkowo-tłuszczowych oraz obsługą osobistej pompy insulinowej.

Matka dziecka rozumie jak powinna realizować zasady samokontroli i leczenia cukrzycy typu 1. Ojciec dziecka nie może pogodzić się z diagnozą lekarską. Próbuje znaleźć wytłumaczenie choroby córki oraz alternatywne metody leczenia cukrzycy. Największą obawą matki jest to, że nie znajdzie odpowiedniego przedszkola dla córki.

Mama pacjentki obawia się również powrotu do pracy i pozostawienia córki w placówce oświatowo-wychowawczej.

\section{Proces pielęgnowania chorego z zastosowaniem terminologii z ICNP ${ }^{\circledR}$}

Podmiot opieki: dziecko 10004266 [7]

Lokalizacja: oddział szpitalny 10009133[7]

Diagnoza: duszność 10029433 + kwasica metaboliczna 10032010 [7]

Cel: bez duszności 10029264 + efektywna równowaga kwasowo-zasadowa 10033663 [7]

Interwencje:

- podanie leku 10040708, środki/przedmiot: insulina 10010400, pielęgniarka 10013333, technika podawania leku 10006322, kaniula dożylna 10020677, kwasica metaboliczna 10032010 [7];

- terapia płynami 10039330, środki/przedmiot: pielęgniarka 10013333, terapia płynami 10031321, kaniula dożylna 10020677 [7];

- monitorowanie statusu oddechu 10012196, środki/ przedmiot: pielęgniarka 10013333, narzędzie do oceny 10002832 [7];

- ocenianie skóry 10041126, środki/przedmiot: pielęgniarka 10013333, narzędzie do oceny 10002832 [7];

- wspieranie statusu psychicznego 10019161, środki/ przedmiot: pielęgniarka 10013333, usługa edukacyjna 10006572 [7];

- zarządzanie objawami 10031965, środki/przedmiot: pielęgniarka 10013333, lekarz 10014522, duszność 10006461, kwasica metaboliczna 10032010 [7]

Wynik: bez duszności 10029264 + efektywna równowaga kwasowo-zasadowa 10033663 [7]

Podmiot opieki: dziecko 10004266 [7]

Lokalizacja: oddział szpitalny 10009133 [7]

Diagnoza: nudności 10000859 + kwasica metaboliczna 10032010 [7]

Cel: bez nudności 10028984 + efektywna równowaga kwasowo-zasadowa 10033663 [7]
Interwencje:

- podanie leku 10040708, środki/przedmiot: insulina 10010400, pielęgniarka 10013333, technika podawania leku 10006322, kaniula dożylna 10020677, kwasica metaboliczna 10032010 [7];

- terapia płynami 10039330, środki/przedmiot: pielęgniarka 10013333, terapia płynami 10031321, kaniula dożylna 10020677 [7];

- zarządzanie wymiotami 10046329, środki/przedmiot: pielęgniarka 10013333, lek 10011866, terapia płynami 10031321, urządzenia do dbania o siebie 10008537 [7];

- zarządzanie nudnościami 10043673, środki/przedmiot: pielęgniarka 10013333, lek 10011866, terapia płynami 10031321 [7];

- monitorowanie statusu fizjologicznego 10012183 , środki/przedmiot: pielęgniarka 10013333, narzędzie do oceny 10002832 [7]

Wynik: bez nudności 10028984 + efektywna równowaga kwasowo-zasadowa 10033663 [7]

Podmiot opieki: dziecko 10004266 [7]

Lokalizacja: oddział szpitalny 10009133, dom 10009030 [7] Diagnoza: hiperglikemia 10027550 [7]

Cel: efektywna odpowiedź na terapię 10036423 [7] Interwencje:

- zmierzenie stężenia glukozy we krwi 10041212, środki/ przedmiot: urządzenie monitorujące 10012177 [7];

- administrowanie lekiem 100255444, środki/przedmiot: insulina 10010400, pielęgniarka 10013333, technika podawania leku 10006322, kaniula dożylna 10020677 [7];

- demonstrowanie sposobu podawania lek 100243544, środki/przedmiot: pielęgniarka 10013333, materiał instruktażowy 10010395 [7];

- monitorowanie statusu fizjologicznego 10012183, środki/przedmiot: pielęgniarka 10013333, narzędzie do oceny 10002832 [7];

- nauczanie o reżimie terapii 10024625, środki/przedmiot: pielęgniarka 10013333, materiał instruktażowy 10010395, dietetyk 10040426 [7];

- nauczanie rodziny o chorobie 10021719 , środki/przedmiot: pielęgniarka 10013333, materiał instruktażowy 10010395, materiał do czytania 10016433 [7]

Wynik: efektywna odpowiedź na terapię 10036423 [7]

Podmiot opieki: dziecko 10004266 [7]

Lokalizacja: oddział szpitalny 10009133, dom 10009030 [7]

Diagnoza: hipoglikemia 10027566 [7]

Cel: efektywna odpowiedź na terapię 10036423[7]

Interwencje:

- zmierzenie stężenia glukozy we krwi 10041212, środki/ przedmiot: urządzenie monitorujące 10012177 [7];

- monitorowanie statusu fizjologicznego 10012183, środki/przedmiot: pielęgniarka 10013333, narzędzie do oceny 10002832 [7];

- administrowanie lekiem 100255444, środki/przedmiot: insulina 10010400, pielęgniarka 10013333, technika podawania leku 10006322 [7]; 
- nauczanie o reżimie terapii 10024625 , środki/przedmiot: pielęgniarka 10013333, materiał instruktażowy 10010395, dietetyk 10040426 [7];

- nauczanie rodziny o chorobie 10021719 , środki/przedmiot: pielęgniarka 10013333, materiał instruktażowy 10010395, materiał do czytania 10016433 [7] Wynik: efektywna odpowiedź na terapię 10036423 [7]

Podmiot opieki: dziecko 10004266, rodzina 10007554[7] Lokalizacja: oddział szpitalny 10009133, dom 10009030[7]

Diagnoza: brak wiedzy o chorobie 10021994 [7]

Cel: adekwatna wiedza 10027112[7]

Interwencje:

- ocenianie wiedzy o chorobie 10030639, środki/przedmiot: pielęgniarka 10013333, narzędzie do oceny 10002832 [7];

- demonstrowanie sposobu podawania leku 10024354, środki/przedmiot: pielęgniarka 10013333, insulina 10010400, usługa edukacji zdrowotnej 10039459, materiał instruktażowy 10010395 [7];

- nauczanie o chorobie 10024116, środki/przedmiot: pielęgniarka 10013333, usługa edukacji zdrowotnej 10039459, materiał instruktażowy 10010395, materiał do czytania 10016433 [7];

- zapewnienie materiału instruktażowego 10024493, środki/przedmiot: materiał instruktażowy 10010395 [7];

- ocenianie przestrzegania zaleceń 10024185, środki/ przedmiot: pielęgniarka 10013333, narzędzie do oceny 10002832 [7];

- administrowanie insuliną 10030417, środki/przedmiot: pielęgniarka 10013333, insulina 10010400 [7]

Wynik: adekwatna wiedza 10027112 [7]

Podmiot opieki: dziecko 10004266, rodzina 10007554 [7] Lokalizacja: oddział szpitalny 10009133, dom 10009030 [7] Diagnoza: brak wiedzy o reżimie leczenia 10021925 [7] Cel: adekwatna wiedza 10027115 [7]

Interwencje:

- demonstrowanie sposobu podawania leku 10024354 środki/przedmiot: pielęgniarka 10013333, insulina 10010400, usługa edukacji zdrowotnej 10039459, materiał instruktażowy 10010395 [7];

- nauczanie o leku 10019470, środki/przedmiot: pielęgniarka 10013333, insulina 10010400, usługa edukacji zdrowotnej 10039459, materiał instruktażowy 10010395, materiał do czytania 10016433 [7];

- administrowanie lekiem 100255444, środki/przedmiot: pielęgniarka 10013333, insulina 10010400 [7];

- identyfikowanie postawy wobec opieki 10009649, środki/przedmiot: pielęgniarka 10013333, urządzenie do oceny 10002734 [7];

- ocenianie postawy wobec reżimu terapii 10024205, środki/przedmiot: pielęgniarka 10013333, urządzenie do oceny 10002734 [7]

Wynik: adekwatna wiedza 10027115 [7]
Podmiot opieki: dziecko 10004266, rodzina 10007554 [7] Lokalizacja: oddział szpitalny 10009133, dom 10009030 [7] Diagnoza: brak wiedzy o reżimie diety 10021939 [7]

Cel: wiedza o reżimie diety 10023772 [7]

Interwencje:

- nauczanie o potrzebach dietetycznych 10046533 , środki/przedmiot: pielęgniarka 10013333, usługa edukacji zdrowotnej 10039459, materiał instruktażowy 10010395 [7];

- ocenianie wiedzy 10033882, środki/przedmiot: pielęgniarka 10013333, urządzenie do oceny 10002734 [7];

- nauczanie o odżywianiu 10024618l, środki/przedmiot: pielęgniarka 10013333, usługa edukacji zdrowotnej 10039459, materiał instruktażowy 10010395 [7];

- ewaluacja odpowiedzi psychospołecznej na instruowanie dotyczące odżywiania 10007111, środki/przedmiot: pielęgniarka 10013333, urządzenie do oceny 10002734 [7]

Wynik: wiedza o reżimie diety 10023772 [7]

Podmiot opieki: dziecko 10004266 [7]

Lokalizacja: oddział szpitalny 10009133, dom 10009030 [7] Diagnoza: nadwaga 10027300 [7]

Cel: waga w granicach normy 10027392 [7]

Interwencje:

- monitorowanie wagi ciała 10032121, środki/narzędzia: pielęgniarka 10013333,urządzenie do oceny 10002734 [7];

- monitorowanie odżywiania 10036032, środki/narzędzia: pielęgniarka 10013333,urządzenie do oceny 10002734 [7];

- nauczanie o odżywianiu 10024618, środki/przedmiot: pielęgniarka 10013333, usługa edukacji zdrowotnej 10039459, materiał instruktażowy 10010395 [7];

- ocenianie postawy wobec statusu odżywienia 10002694 , środki/narzędzia: pielęgniarka 10013333, urządzenie do oceny 10002734 [7];

- współdziałanie z dietetykiem 10040435, środki/przedmiot: dietetyk 10040426, usługi dietetyczne

10013435 [7];

- zapewnienie materiału instruktażowego 10024493 , środki/przedmiot: materiał instruktażowy 10010395 [7];

- doskonalenie reżimu diety 10036447: środki/przedmiot: pielęgniarka 10013333, dietetyk 10040426, narzędzie do oceny 10002734, materiał do czytania 10016433 [7]

Wynik: waga w granicach normy 10027392 [7]

Podmiot opieki: rodzina 10007554[7]

Lokalizacja: oddział szpitalny 10009133, dom 10009030 [7]

Diagnoza: niepokój 10000477 + hospitalizacja 10009122 [7]

Cel: zredukowany niepokój 10027858 [7]

- ocenianie niepokoju 10041745, środki/przedmiot: pielęgniarka 10013333, narzędzie do oceny 10002734 [7];

- zarządzanie niepokojem 10031711, środki/przedmiot: pielęgniarka 10013333[7];

- Use Calming Technique 10050299, środki/przedmiot: pielęgniarka 10013333[7]; 
- demonstrowanie technik relaksacyjnych 10024365 , środki/przedmiot: pielęgniarka 10013333 [7];

- promowanie pozytywnego statusu psychologicznego 10032505, środki/przedmiot: pielęgniarka 10013333 [7];

- informowanie o hospitalizacji 10042480, środki/przedmiot: pielęgniarka 10013333, lekarz 10014522 [7];

- implementacja pielęgnacji zapewniającej komfort 10039705, środki/przedmiot: pielęgniarka 10013333, urządzenia do dbania o siebie 10008537 [7];

- towarzyszenie pacjentowi 10042613, środki/przedmiot: pielęgniarka 10013333;

- zapewnienie wsparcia emocjonalnego 10027051, środki/przedmiot: pielęgniarka 10013333[7]

Wynik: zredukowany niepokój 10027858[7]

Podmiot opieki: dziecko 10004266, rodzina 10007554[7]

Lokalizacja: dom 10009030, szkoła 10017537 [7]

Diagnoza: zaburzona socjalizacja 10001022 [7]

Cel: zdolny/a do socjalizacji 10028282 [7]

Interwencje:

- nauczanie społeczności o chorobie 10038203, środki/ przedmiot: pielęgniarka 10013333, materiał instruktażowy 10010395, materiał do czytania 10016433 [7];

- nauczanie kadr dydaktycznych o chorobie 10038226 , środki/przedmiot: pielęgniarka 10013333, materiał instruktażowy 10010395, materiał do czytania 10016433 [7];

- ocenianie możliwości 10026040, środki/przedmiot: pielęgniarka 10013333, narzędzie do oceny 10002734 [7];

- identyfikowanie przeszkody w komunikacji 10009683, środki/przedmiot: pielęgniarka 10013333, narzędzie do oceny 10002734 [7];

- ocenianie postawy wobec reżimu terapii 10025205 , środki/przedmiot: pielęgniarka 10013333, narzędzie do oceny 10002734 [7];

- ocenianie stopnia radzenia sobie rodziny 10026600 , środki/przedmiot: pielęgniarka 10013333, narzędzie do oceny 10002734, pracownik socjalny 10024088 [7];

- oceniania wsparcia społecznego 10024298, środki/ przedmiot: pielęgniarka 10013333, pracownik socjalny 10024088 [7]

Wynik: zdolny/a do socjalizacji 10028282 + szkoła 10017537 [7]

Podmiot opieki: rodzina 10007554 [7]

Lokalizacja: dom 10009030 [7]

Diagnoza: ryzyko zaburzenia zdolności do sprawowania opieki rodzicielskiej 10015198 [7]

Cel: efektywne sprawowanie opieki rodzicielskiej 10027955 [7]

Interwencja:

- zapewnienie wsparcia emocjonalnego 10027051, środki/przedmiot: pielęgniarka 10013333, lekarz 10014522, proces psychologiczny 10015961 [7];

- współdziałanie z lekarzem 10023565, środki/przedmiot: lekarz 10014522 [7];

- ocenianie niepokoju 10041745, środki/przedmiot: pielęgniarka 10013333, narzędzie do oceny 10002734 [7];
- zarządzanie niepokojem 10031711, środki/przedmiot: pielęgniarka 10013333, odpowiedź psychologiczna 10015974, usługodawca usług zdrowotnych 10003989[7];

- promowanie wsparcia rodziny 10036078, środki/ przedmiot: pielęgniarka 10013333, pracownik socjalny 10024088, terapia rodzinna 10007667[7];

- współdziałanie z rodziną 10035887, środki/przedmiot: pielęgniarka 10013333, terapia rodzinna 10007667[7]

Wynik: efektywne sprawowanie opieki rodzicielskiej 10027955 [7].

\section{OMÓWIENIE}

Cukrzyca jest współczesną chorobą społeczną i cywilizacyjną. Jest to grupa chorób metabolicznych charakteryzujących się hiperglikemią wynikającą z defektu wydzielania i/lub działania insuliny. Przewlekła hiperglikemia w cukrzycy prowadzi do uszkodzenia, zaburzenia czynności i niewydolności wielu narządów, w tym głównie oczu, nerek, nerwów, serca i naczyń krwionośnych $[8,9,10]$.

Cukrzyca typu 1 jest jedną $\mathrm{z}$ najczęstszych chorób przewlekłych wieku rozwojowego. W ostatnich latach na całym świecie obserwuje się stały wzrost zachorowalności $[11,12]$.

Według Międzynarodowej Federacji ds. Cukrzycy (International Diabetes Federation - IDF) na świecie 1,1 miliona dzieci i młodzieży w wieku poniżej 20 lat choruje na cukrzycę typu 1 [10].

Szacuje się, iż do 2025 roku liczba zachorowań w Polsce wzrośnie 4-krotnie i dotyczyć będzie zwłaszcza dzieci w wieku 0-9 lat $[13,14]$.

Objawy kliniczne cukrzycy typu 1 zależą od wieku zachorowania. Im młodszy wiek zachorowania, tym bardziej burzliwie pojawiają się i przebiegają objawy kliniczne. Są one głównie związane są z hiperglikemią i diurezą osmotyczną. Niektóre objawy kliniczne występują $\mathrm{w}$ trakcie leczenia i pozostają w związku z podażą insuliny lub też niewłaściwym doborem dawki leku [15].

Najczęstszym i najpoważniejszym powikłaniem leczenia cukrzycy jest hipoglikemia. Hipoglikemię uznaje się za czynnik ograniczający skuteczność leczenia cukrzycy typu $1[16,17,18]$.

Celem leczenia cukrzycy typu 1 jest osiągnięcie dobrej kontroli metabolicznej z utrzymaniem w granicach normy stężenia glukozy we krwi, wartości hemoglobiny glikowanej (HbA1c $\leq 7,0 \%$ ), ciśnienia tętniczego, parametrów gospodarki lipidowej oraz masy ciała, przy równoczesnym unikaniu hipoglikemii. Dodatkowym celem leczenia dzieci, młodzieży oraz młodych dorosłych z cukrzycą typu 1 jest uzyskanie i utrzymanie prawidłowego, harmonijnego rozwoju fizycznego (wzrostu i masy ciała) oraz przebiegu okresu dojrzewania odpowiedniego do wieku i płci, przy jednoczesnym zapewnieniu komfortu życia dziecka i jego rodziny [9].

W kontroli metabolicznej dąży się do utrzymania stężenia HbAlc $\leq 6,5 \%$ przy stabilnej glikemii i zminimalizowaniu epizodów hipoglikemii. To postępowanie pozwala zapobiec występowaniu ostrych i przewlekłych powikłań oraz umożliwia prowadzenie normalnego, aktywnego życia rodzinnego, zawodowego i społecznego [9]. 
Choroby przewlekłe wymagają aktywnego, nieustającego leczenia. Zmuszają do stosowania różnych technik działania oraz do regularnych kontaktów z różnymi członkami zespołu terapeutycznego [19].

Dzieci i młodzież z cukrzycą typu 1 i ich opiekunowie powinni czynnie uczestniczyć $\mathrm{w}$ procesie leczenia. Terapia cukrzycy typu 1 obejmuje odpowiednią insulinoterapię, prawidłowe żywienie, wysiłek fizyczny, edukację zdrowotną oraz samokontrolę prowadzoną przez pacjentów $[9,20,21]$.

Sprawowanie opieki nad dzieckiem chorym na cukrzycę typu 1 wiąże się z ryzykiem wystąpienia zespołu wypalenia u rodziców. Uważa się, że profesjonalna opieka psychologiczna nad dzieckiem $\mathrm{z}$ cukrzycą typu 1 powinna obejmować również jego rodzinę $[22,23,24]$.

$\mathrm{ICNP}^{\circledR}$ jest prostym, wystandaryzowanym narzędziem wspierającym ogólną i specjalistyczną opiekę pielęgniarskim $[4,5,25]$. Umożliwia zastąpienie większości „tradycyjnych" diagnoz i działań pielęgniarskich podejmowanych wobec chorych z cukrzycą i jego rodzin "gotową" terminologią ze słownika ICNP ${ }^{\circledR}$ [25].

\section{PODSUMOWANIE}

Właściwa opieka pielęgniarska, intensywna edukacja diabetologiczna oraz optymalne leczenie jest niezbędne, aby zapewnić najlepszą jakość życia minimalizując jednocześnie ryzyko wystąpienia ostrych zaburzeń metabolicznych i przewlekłych powikłan.

Stosowanie terminologii z ICNP ${ }^{\circledR}$ umożliwia stworzenie szczegółowego i holistycznego procesu pielęgnowania nad dzieckiem z DMT1 i jego rodziną.

$\mathrm{Na}$ podstawie uzyskanych informacji sformułowano diagnozy pielęgniarskie: duszność, nudności, hiperglikemia, hipoglikemia, brak wiedzy o chorobie, brak wiedzy o reżimie leczenia, brak wiedzy o reżimie diety, nadwaga, niepokój, zaburzona socjalizacja, ryzyko zaburzenia zdolności do sprawowania opieki rodzicielskiej.

Podjęte interwencje pielęgniarskie pomogą osiągnąć odpowiedni poziom życia oraz obniżą ryzyko wystąpienia ostrych zaburzeń metabolicznych oraz przewlekłych powikłań cukrzycy.

\section{ORCID}

Julita Ronkowska (iD) https://orcid.org/0000-0001-7937-0060

Anna Stefanowicz-Bielska (iD https://orcid.org/0000-0002-1896-5551

\section{REFERENCES/PIŚMIENNICTWO}

1. Rechenberg $K$, Whittemore $R$, Holland $M$, et al. General and diabetes-specific stress in adolescents with type 1 diabetes. Diabetes Res Clin Pract. 2017;130:1-8. D0I: 10.1016/j.diabres.2017.05.003.

2. Blair JC, McKay A, Ridyard C, et al. Continuous subcutaneous insulin infusion versus multiple daily injection regimens in children and young people at diagnosis of type 1 diabetes: pragmatic randomised controlled trial and economic evaluation, BMJ. 2019;365:1-12. D0l: 10.1136/bmj.I1226

3. Rechenberg K, Grey H, Sadler L. Stress and Posttraumatic Stress in Mothers of Children With Type 1 Diabetes J Fam Nurs. 2017;23(2):201-225. D0I: $10.1177 / 107484071668754$
4. Rabelo-Silva ER, Dantas Cavalcanti AC, Goulart Caldas MCR, et al. Advanced Nursing Process quality: Comparing the International Classification for Nursing Practice (ICNP) with the NANDA-International (NANDA-I) and Nursing Interventions Classification (NIC), J Clin Nurs. 2016;26:379-387. D0I: 10.1111/jocn.13387

5. https://www.icn.ch/what-we-doprojectsehealth-icnptm/about-icnp, dostęp: 12.07.2020

6. Ślusarska B. Implementacje praktyczne wybranych klasyfikacji diagnoz i interwencji pielęgniarskich dla pielęgniarstwa polskiego Zdrowie Publiczne i Zarządzanie. 2016;14(1):11-22. D0l: 10.4467/208426270Z.16.002.5564

7. https://www.icn.ch/what-we-do/projects/ehealth/icnp-browser, dostęp: 12.07.2020

8. Petersmann A, Müller-Wieland D, Müller UA, et al. Definition, Classification and Diagnosis of Diabetes Mellitus. Exp Clin Endocrinol Diabetes. 2019;127:S1-S7. D0I: 10.1055/a-1018-9078

9. Polskie Towarzystwo Diabetologiczne: Zalecenia kliniczne dotyczące postępowania u chorych na cukrzycę 2020. Diabetologia Praktyczna. 2020;6,1:1-106. D0I: 10.5603/ DK.2020.0001

10. https://diabetesatlas.org/en/sections/worldwide-toll-of-diabetes.html, dostęp: 09.08.2020

11. Orzan A, Novac C, Mihu M, et al. Type 1 diabetes and thyroid autoimmunity in children. Maedica (Buchar). 2016;11(4):308-312.

12. Elsamahy MH, Elhenawy $\mathrm{YI}$, Altayeb $\mathrm{N}$. Long-term prognosis of type 1 diabetes in relation to the clinical characteristics at the onset of diabetes. Egyptian Pediatric Association Gazette. 2017;65(3):90-94. D0I:10.1016/j .epag.2017.04.004

13. Jarosz-Chobot P, Polańska J, Szadkowska A, et al. Rapid increase in the incidence of type 1 diabetes in Polish children from 1989 to 2004, and predictions for 2010 to 2025. Diabetologia. 2011;54(3):508-515. D0I:10.1007/s00125-010-1993-4

14. Chobot A, Polanska J, Brandt A, et al. Updated 24-year trend of Type 1 diabetes incidence in children in Poland reveals a sinusoidal pattern and sustained increase. Diabet Med. 2017;34(9):1252-1258. D01:10.1111/dme.13345

15. Górska M. Obraz kliniczny cukrzycy typu 1. [w:] Sieradzki J, red. Cukrzyca. Gdańsk: Wyd. Via Medica; 2006, s. 312-318.

16. Derkacz M, Chmiel-Perzyńska I, Nowakowski A. Problemy hipoglikemii w cukrzycy. Curr. Prob. Psychiatry. 2011;12(4):569-574.

17. Hermanns N, Kulzer B, Kubiak T, et al. The effect of an education programme (HyPOS) to treat hypoglycaemia problems in patients with type 1 diabetes. Diabetes Metab. Res. Rev. 2007;23:528-538.

18. Mianowska B, Szadkowska A, Młynarski W. Hipoglikemia w przebiegu cukrzycy typu 1 u dzieci i młodzieży — charakterystyka, zapobieganie, leczenie. Stand. Med. Pediatr. 2010;7:426-433.

19. Tatoń J, Czech A. Spełniamy wyzwanie: Personalistyczna diabetologia w praktyce. Metodologiczny zarys personalistycznie ujętej edukacji terapeutycznej psychospołecznej osób z cukrzycą — własne doświadczenia oparte na EBM. Med. Metab. 2011;XV(2):41-51.

20. Cradock $S$, Cranston C. Type 1 diabetes education and care: time for a rethink? Diabet. Med. 2012;29:159-160.

21. Christie D, Thompson R, Sawtell M, et al. Structured, intensive education maximising engagement, motivation and long-term change for children and young people with diabetes: a cluster randomised controlled trial with integral process and economic evaluation - the CASCADE study. Health Technol Assess. 2014;18(20):1-202. D0I: $10.3310 /$ hta18200

22. Nitka-Siemińska A, Myśliwiec M, Landowski J, et al. Zespół wypalenia u rodziców osób chorych na cukrzycę typu 1. Diabet. Prakt. 2008;9(2):76-81.

23. Horsch A, McManus F, Kennedy $P$, et al. Anxiety, depressive, and posttraumatic stress symptoms in mothers of children with type 1 diabetes. J. Trauma. Stress. 2007;20(5):881-891. D0I: 10.1002/jts.20247

24. Sendela J, Zduńczyk B, Trippenbach-Dulska H, et al. Występowanie objawów depresji u dzieci w wieku szkolnym z cukrzycą typu 1 - badanie kwestionariuszowe, Psychiatr. Pol. 2015;49(5):1005-1016. D0I: 10.12740/PP/35649

25. Grabowska H, Grabowski W, Gaworska-Krzemińska A. Mapowanie fraz opisujących diagnozy $\mathrm{i}$ interwencje pielęgniarskie $w$ opiece nad chorym $z$ cukrzycą $z$ wykorzystaniem ICNP®. Pielęgniarstwo XXI wieku. 2014;48(3):37-41.

Manuscript received/Praca zgłoszona do czasopisma: 15.07.2020

Manuscript accepted/Praca zaakceptowana do druku: 04.09.2020

Translation/Tłumaczenie: Anna Sarad, EKO-BAU GRZEGORZ KLEIN ul. Osiedlowa 880-298 Gdańsk 